EDITORIAL

\title{
Stories in haematology and wine
}

(c) The Author(s), under exclusive licence to Springer Nature Limited 2021

Bone Marrow Transplantation (2021) 56:2619-2621; https://doi.org/ 10.1038/s41409-021-01388-6

'We are human because we recount stories and myths...'

Herodotus (The Histories).

Greek historian. 484-425 B C.

As far as I can remember news and events presented by the media (print and television) were rather dry and factual until recently. Now 'news' is presented as stories and newscasters/ presenters have become celebrities, like oenologists/wine consultants or chefs, among others. Perhaps that is a good thing, stories I mean, and Herodotus was a marvellous storyteller, although memory is a fragile thing. Cicero called him 'The Father of Western History' but some of Herodotus' accounts may rely on imagination rather than clear and undisputed memory. One of the stories recounted in The Histories [1], is the assassination of Candaules by his favourite manservant Gyges after he asked Gyges to look at Candaules' naked wife, whom he thought was the most beautiful woman in the world Fig. 1. It turned out to be a bad idea, and Candaules came to a sticky end.

As haematologists and haemopoietic cell transplanters (HCT), the story of the unravelling of the HLA system in humans is very important. HLA; HLA2 (human leucocyte antigen) was first described in 1958, but as Thorsby says, it really should be called the 'major immune response complex, MIRC' [2]. The story represents a remarkable example of cooperation between scientists from many different countries. Thorsby claims that the International Histocompatibility Workshops (the first in 1964 was organised by Bernard Amos at Duke University, North Carolina) were of major importance in unravelling the HLA system. The initial workshops were 'wet' where investigators carried out experiments in the same laboratory using the same panel of cells. Although many scientists were involved the name that is probably the best known to

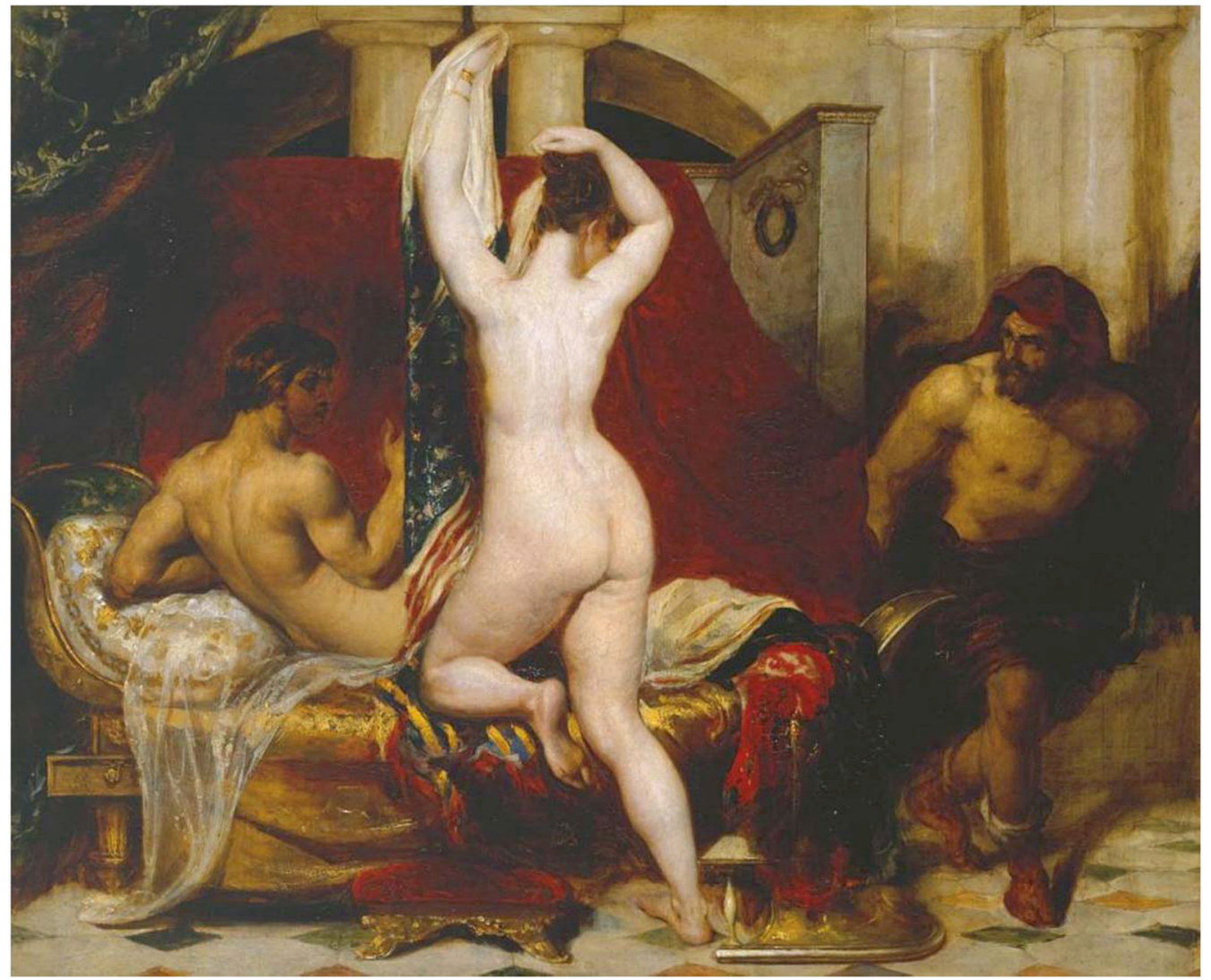

Fig. 1 Nyssia. Candaules, King of Lydia, showing his wife Nyssia, to Gyges. William Etty (1787-1849). Tate Britain. Public domain including U.S.A.

Received: 25 May 2021 Revised: 27 May 2021 Accepted: 21 June 2021

Published online: 6 July 2021 
clinicians is the late Jon J. van Rood (1926-2017) whom I met on a number of occasions at the annual meetings of the EBMT.

In the 1970s and the early 1980s, a fully HLA matched sibling donor was always sought for HCT, but the chances of finding one were dependent on family size [3]. However, the pool of donors for HCT has now widened to include unrelated donors, umbilical cord blood and haplo-identical transplants. The HLA system is highly polymorphic and originally depended on detection of $A, B, C$ and DR by a complement dependent microlymphotoxicity assay using Terasaki plates and human antibodies derived from alloimmunised donors. With the development of modern technology to include a number of PCR based techniques such as the use of sequencespecific primers (PCR-SPPs), sequence specific oligonucleotides (PCRSSOs) and sequence-based typing, more accurate HLA has become available. Until recently, Sanger sequencing was the most accurate method available but now, so-called Next-Generation Sequencing (NGS) offers a higher level. Ironically the selection of donors has become more complex as many individuals who were believed to be full matches have minor HLA differences. To assist in the choice of donors a number of authors have suggested 'permissible' mismatches when selecting donors for HCT.

HLA matching, however, is not the only consideration. Alloreactive T-cells can recognise non-self, allogeneic tissues. This is called T-cell alloreactivity and can be important in Graft versus Host Disease (GvHD) and the Graft versus Leukaemia (GvL) effect.

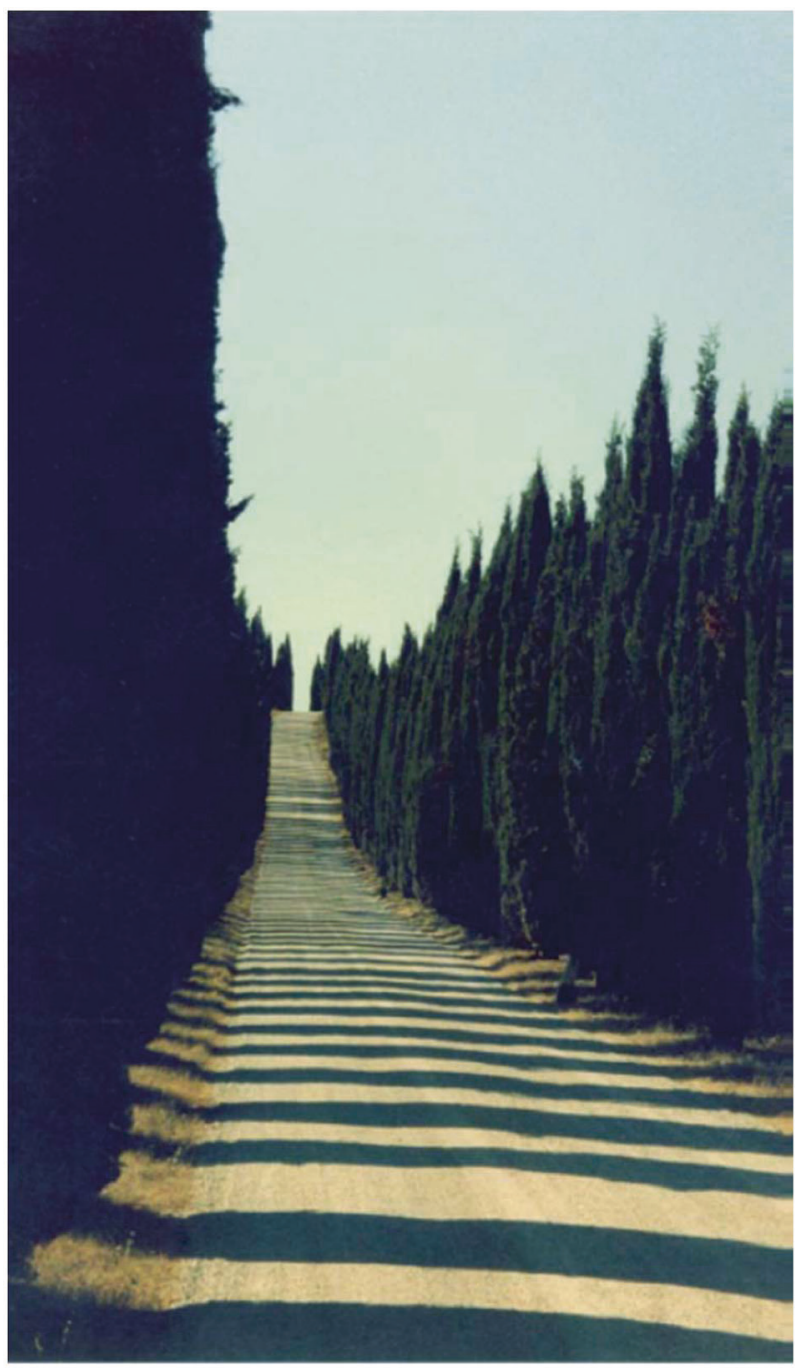

Fig. 2 Tuscany. Evening sun near San Gimignano, Tuscany. Photograph Shaun R. McCann.
(For a full discussion of histocompatibility in HCT see The EBMT Handbook: Hemopoietic Stem Cell Transplantation and Cellular Therapies. 2019. pp 61-68).

Are there stories told about wine? Yes, there are many but I will only discuss one. Tuscany Fig. 2 is a large region in Italy, 23,000 sq $\mathrm{km}$, with 3.8 million inhabitants and many grape varieties. Most people associate Tuscan wine with the Sangiovese grape but a Piedmontese wine maker wanted to make a Cabernet Sauvignonbased wine. Why? Remembering that Piedmont had been under

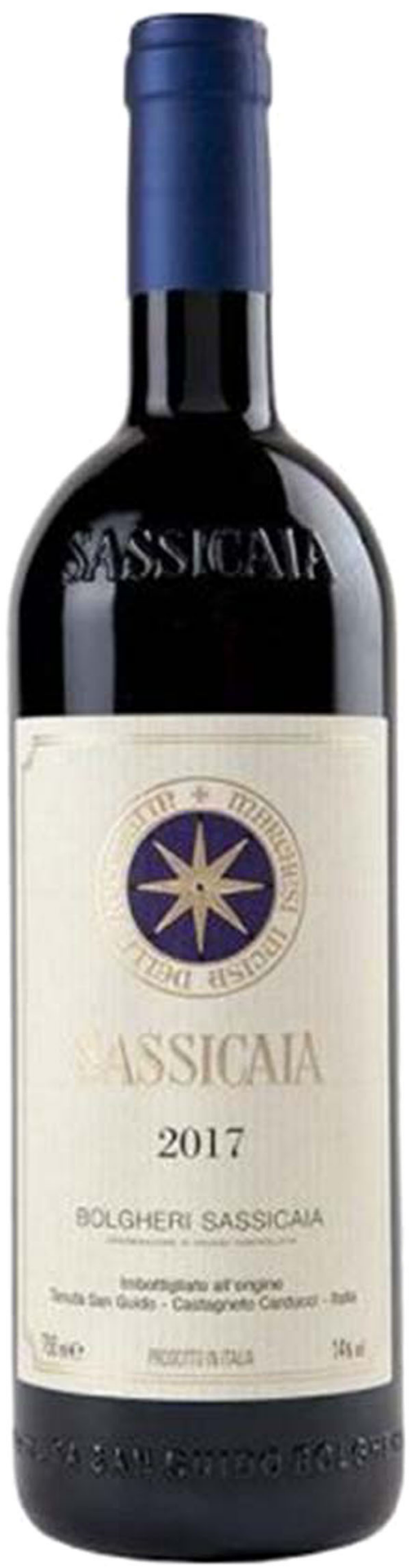

Fig. 3 Super Tuscan. A bottle of Sassicaia. 
French rule for some time it is not surprising that a Piedmontese named Mario Incisa della Rocchetta wanted to make wine from Cabernet Sauvignon grapes, used in many of the famous French wines from Bordeaux. The King of Italy, Victor Emanuel III preferred to speak French and many wine makers in Italy were anxious to imitate the taste of French wine. In 1930 Mario della Rocchetta married Clarice della Gherardesca, heir to a famous Pisan family [4].

In 1944, della Rocchetta planted the Tenuta San Guido (in Bolgheri in the Maremma on the western coast of Tuscany) estate's vineyard, Castiglioncello, with Cabernet Sauvignon and Cabernet Franc instead of traditional Tuscan grapes. Rocchetta also differed from most Tuscan wine makers by ageing his wine in French barriques $(225 \mathrm{~L})$ rather than the tonneaux $(300-750 \mathrm{~L})$ favoured in Tuscany. Initially the wine was made for personal and family consumption. Piero Antinori, a fellow wine maker, tasted the wine and suggested it should be sold. He engaged Giacomo Tachis, an oenologist from Piedmont, to oversee commercial production. Tachis had been greatly influenced by Èmile Peynaud, a famous Bordeaux oenologist [5] and Rochetta's wine, called Sassicaia, was launched as a common table wine (vino da tavola) in 1968. In 1978, at a blind tasting organised by Decanter magazine in London, a panel of experts voted the 1972 Sassicaia the best Cabernet Sauvignon from amongst 33 wines from eleven countries, including the great wines of France. This secured the world-wide reputation of Sassicaia Fig. 3 .

Sassicaia could not be marketed as a Chianti Classico, as it is not made from the Sangiovese grape, so, it became known as a 'Super Tuscan'. It is unclear who was the first person to use the term. Some credit Robert Parker and others, Nicolas Belfrage, Master of Wine and English expert on Italian wine. Undoubtedly a great wine, but in my view, it is sold for ridiculously high prices. When Giacomo Tachis was asked in 2004: 'why would some people pay $\$$ 200 for a single bottle of wine and others pay $\$ 20$ ? He replied, 'II Prezzo del vino e l'imbecillita del cliente (the stupidity of the client determines the price). I agree with Tachis and a well-made Chianti Classico at $<\$ 20$ is still my preference, although Sassicaia is probably the weekend tipple of anaesthesiologists, obstetricians and oncologists.

This is a version of the story of Sassicaia but as Herodotus found: 'each person remembers something different-different and differently' [6] there probably are other ones. One thing is certain, Sassicaia is now considered by some people to be the premier Tuscan red. However, my personal preference is to drink wines made from Cabernet Sauvignon from Bordeaux and Sangiovese from Tuscany.

Whatever your particular taste, a little knowledge about the provenance and the story behind the wine you are drinking may add to your enjoyment.

Shaun R. McCann (D) ${ }^{1 凶}$

'Emeritus, Department of Haematology, Trinity College, Dublin, Ireland. ${ }^{\bowtie}$ email: shaunrmccann@gmail.com

\section{REFERENCES}

1. Herodotus. The Histories. Revised edition. New York New York, USA: Penguin Classics, Penguin Books; 1972.

2. Thorsby E. A short history of HLA. Tissue Antigens. 2009; https://doi.org/10.1111/ j.1399.2009.01291.x.

3. O'Riordan J, Finch A, McCann SR. Probability of finding compatible sibling donors for bone marrow transplantation in Ireland. Bone Marrow Transplant 1992;9:27-30.

4. Pazzano S. How Sassicaia was born. 2019. https://www.informacibo.it/sassicaiastoria-vino-italiano/.

5. Nesto B, Di Savino F. Chianti classico: the search for tuscany's noblest wine Oakland, California: University of California Press; 2016. ISBN 978-0-520-28442-5.

6. Kapuśińsk R. Travels with herodotus. New York, New York, USA: Penguin books; 2008.

\section{COMPETING INTERESTS}

The author declares no competing interests.

\section{ADDITIONAL INFORMATION}

Correspondence and requests for materials should be addressed to S.R.M.

Reprints and permission information is available at http://www.nature.com/ reprints

Publisher's note Springer Nature remains neutral with regard to jurisdictional claims in published maps and institutional affiliations. 